\title{
Bi-Base Composite Solders for Mounting Power Semiconductor
}

\section{Devices}

\author{
Yoshikazu Takaku*, Ikuo Ohnuma*, Yasushi Yamada**, Yuji Yagi**, Yuji Nishibe**, Yuji Sutou*, \\ Ryosuke Kainuma*** and Kiyohito Ishida* \\ *CREST-JST, Dept. Mater. Sci., Tohoku University, Sendai 980-8579, Japan \\ ** Toyota Central R\&D Labs., Inc., Aichi 470-0205, Japan \\ *** CREST-JST, IMRAM, Tohoku Univ., Sendai 980-8577, Japan
}

(Received September 14, 2007; accepted January 28, 2008)

\begin{abstract}
A novel Bi-base solder for mounting semiconductor power devices on inverters used in hybrid and fuel-cell vehicles was studied. The solder consists of Bi-base matrix (m.p. (melting point) $=270^{\circ} \mathrm{C}$ ), which facilitates high-temperature soldering, and dispersion particles of a $\mathrm{Cu}-\mathrm{Al}-\mathrm{Mn}$ alloy, whose thermoelastic martensitic microstructure is expected to relax the thermal stress. The tensile strength of the developed solders was found to be remarkably improved compared with that of pure Bi. Results of tensile tests at elevated temperatures showed greater elongation and lower strength than those at room temperature. However, sufficient tensile strength was still remained at $195^{\circ} \mathrm{C}$. Effects of the CTE (coefficient of thermal expansion) and the surface substance of chips and substrates on the IMC (intermetallic compound) formation and thermal cycling properties were investigated. Even after 1983 thermal cycles between $-40^{\circ} \mathrm{C}$ and $200^{\circ} \mathrm{C}$, neither intermetallic compounds nor cracks were observed at the $\mathrm{Cu} / \mathrm{Bi}$-base solder interfaces in the CTE matched samples.
\end{abstract}

Keywords: Bi-Base Composite Solder, CuAlMn Powder, Mechanical Property, IMC (intermetallic compound), Thermal Cycling Test

\section{Introduction}

In the next generation semiconductor power devices, high current density and high voltage I (the electric current)- $\mathrm{V}$ (voltage source) properties as well as heat resistance are required. However, conventional $\mathrm{Si}$ has a temperature limitation of $150^{\circ} \mathrm{C}$, which is not sufficient for future applications. On the other hand, for compound semiconductor power devices, such as $\mathrm{GaN}$ and $\mathrm{SiC}$ are applicable to high-temperature operations beyond $200^{\circ} \mathrm{C} .[1,2]$ Consequently, exposure of power devices to severe thermal stress caused by the expanded temperature hysteresis between $-40^{\circ} \mathrm{C}$ and above $200^{\circ} \mathrm{C}$, which are assumed to occur in the cold winter weather and in full-powered engine rooms, respectively, is problematic.

As well as high-temperature power devices, high-temperature solders applicable above $250^{\circ} \mathrm{C}$ are indispensable for the inter-connection in electronic packaging. However, only harmful substances, such as $\mathrm{Pb}\left(\mathrm{m} . \mathrm{p} .=327^{\circ} \mathrm{C}\right.$ ), $\mathrm{Cd}\left(321^{\circ} \mathrm{C}\right)$ and $\mathrm{Tl}\left(303^{\circ} \mathrm{C}\right)$, and expensive alloys, such as
$\mathrm{Au}-20 \mathrm{mass} \% \mathrm{Sn}\left(280^{\circ} \mathrm{C}\right), \mathrm{Au}-3.5 \mathrm{mass} \% \mathrm{Si}\left(363^{\circ} \mathrm{C}\right)$ and $\mathrm{Au}-12.5 \mathrm{mass} \% \mathrm{Ge}\left(361^{\circ} \mathrm{C}\right)$, have appropriate melting points for high temperature use. If their ductility and weak strength could be improved, $\mathrm{Bi}$ and its alloys $\left(271^{\circ} \mathrm{C}\right)$ would be exceptional candidates for high-temperature solders with not only suitable melting point but also reasonable cost. To overcome such problems, our group has proposed the use of in-situ composite solders of $\mathrm{Bi}-\mathrm{Cu}-\mathrm{Sb}, \mathrm{Bi}-\mathrm{Cu}-\mathrm{Sn}$ and $\mathrm{Bi}-\mathrm{Cu}-\mathrm{Zn}$ ternary alloys produced by rapid quenching processes such as gasatomizing and melt spinning methods.[3] Their microstructure consists of Bi-base matrix $\left(270^{\circ} \mathrm{C}\right)$ which facilitates high-temperature soldering, and fine dispersion particles of $\mathrm{Cu}-\mathrm{X}$ IMCs, which bring about strengthening of the solder itself. However, not only strength but also thermal stress resistance are simultaneously required in solder materials.

The bcc- $\beta$ phase in $\mathrm{Cu}-\mathrm{Al}-\mathrm{Mn}$ alloys exhibits thermoelastic martensitic transformation which can be con- 
trolled by composition, heat treatment and applied stress.[4-7] This martensitic phase shows extensive ductility, which is expected to relax the thermal stress when martensitic particles are dispersed in the Bi solder matrix. Fortunately, $\mathrm{Cu}$-base alloys are immiscible with the Bi matrix, which means that the desirable properties of martensitic particles would not be dissipated. In the present study, the fabrication process of martensitic particle reinforced Bi base solders, the microstructural characteristics and mechanical properties of the composite solders, and the thermal cycle properties of the joined assemblies were investigated.

\section{Experimental Procedure}

\subsection{Fabrication of the composite solder}

Martensitic powder of a $\mathrm{Cu}-23 \mathrm{Al}-2 \mathrm{Mn}$ (at.\%) alloy was prepared by a gasatomizing method. It is difficult to mix Cu-base powder with a Bi melt because the wettability of $\mathrm{Cu}$ by a $\mathrm{Bi}$ melt is quite poor. To solve this problem, electroless nickel was plated onto the surface of each particle using the two types of solution listed in Table 1.[8] Then, the Ni-coated powder was mixed with a $\mathrm{Bi}$ melt at $500^{\circ} \mathrm{C}$ for $5 \mathrm{~min}$ in a quartz tube encapsulated with decompressed Ar gas. During the mixing process, not only $\mathrm{Cu}$-base particles but also $\mathrm{Bi}_{3} \mathrm{Ni}$ precipitates, which formed by a reaction between the Ni coating and $\mathrm{Bi}$, were homogeneously dispersed in the Bi melt. As a result, the obtained composite solder consisted of $60 \% \mathrm{Bi}$, $30 \% \mathrm{Cu}-23 \mathrm{Al}-2 \mathrm{Mn}$ particles and $10 \% \mathrm{Bi}_{3} \mathrm{Ni}$ precipitates in volume fraction.

\subsection{Microstructure and mechanical properties}

The microstructure and composition were examined by an OM (optical microscope) and EPMA (electron probe micro analyzer: JEOL JXA-8100). The transformation temperature was determined by DSC (differential scanning calorimetry: Netzsch DSC-404) referring to heating curves. The measurements were carried out in an argon gas flow, with heating and cooling rates of $5^{\circ} \mathrm{C} /$ min, using sintered $\mathrm{Al}_{2} \mathrm{O}_{3}$ crucibles.

Tensile test specimens were prepared from cast ingots $(10 \mathrm{~mm} \phi \times 60 \mathrm{~mm})$ of composite solders and pure Bi. Stress-strain properties were measured by a tensile test at a strain rate of $10^{-3} / \mathrm{s}$ at temperatures of $-40^{\circ} \mathrm{C}, 25^{\circ} \mathrm{C}$, $105^{\circ} \mathrm{C}$ and $195^{\circ} \mathrm{C}$.

The coefficient of thermal expansion (CTE) was measured by a dilatometer (Netzsch TASC 414/3) in the temperature range between $-40^{\circ} \mathrm{C}$ and $200^{\circ} \mathrm{C}$ with heating and cooling at rates of $5^{\circ} \mathrm{C} / \mathrm{min}$.
Table 1. The bath composition for electroless coating $\mathrm{Ni}$ on $\mathrm{Cu}-\mathrm{Al}$--Mn powder by dropping method. [8]

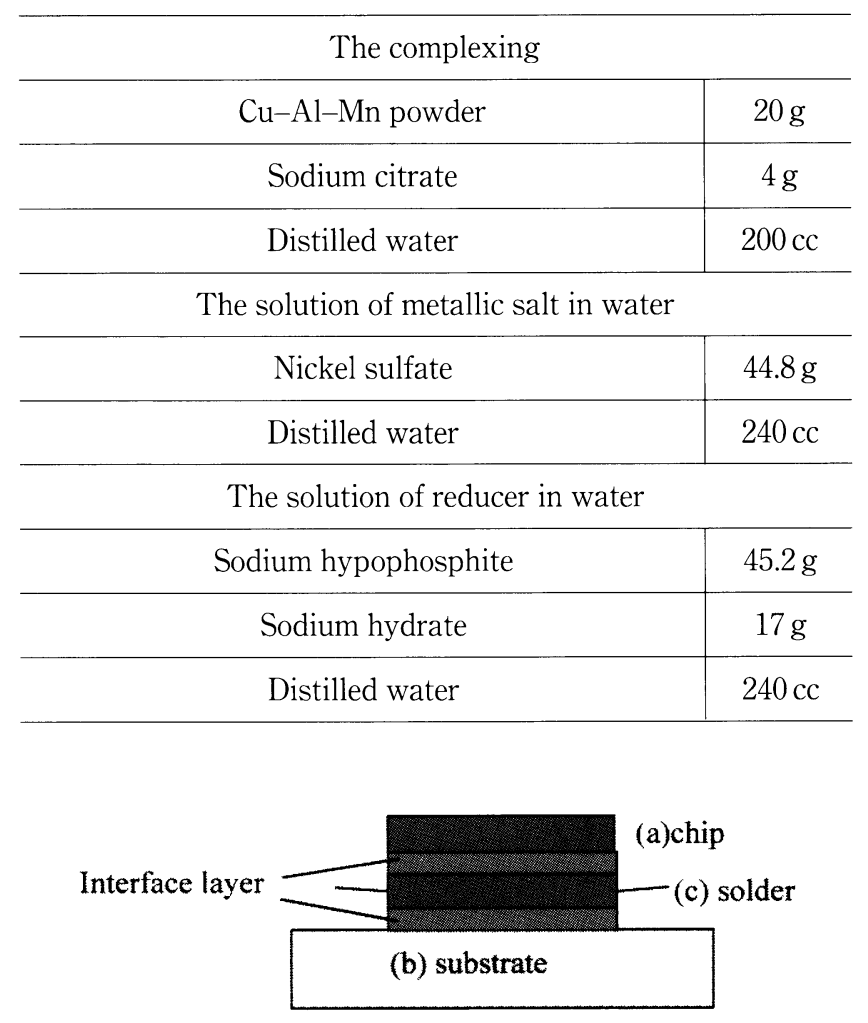

Fig. 1. Illustration of a jointed sample.

\subsection{Thermal cycling test}

Figure 1 shows a schematic illustration of a jointed sample of a Ni-plated semiconductor chip (IGBT: $\mathrm{Si} / \mathrm{Ni}$ ) or its imitation (CIC: laiminated $\mathrm{Cu} / \mathrm{FeNi} / \mathrm{Cu}$ plate), and a solder and substrate (CIC or DBA) which were stacked and soldered on a hot plate in a glove box filled with $\mathrm{Ar}$ gas. Details of each element are shown in Table 2.

Thermal cycling tests were carried out on the jointed assemblies in air. Microstructure evolution and occurrence of voids, cracks and fractures were examined in the cross sections of treated samples and the reliability of solder joints were evaluated.

\section{Results and Discussion}

\subsection{Microstructure of composite solder}

The as-cast microstructure of a composite solder is shown in Fig. 2(a). It can be seen that the $\mathrm{Cu}-\mathrm{Al}-\mathrm{Mn}$ particles and $\mathrm{Bi}_{3} \mathrm{Ni}$ precipitates are homogeneously dispersed in the Bi matrix. According to the EPMA measurement, the composition of the particles remained $\mathrm{Cu}-23 \mathrm{Al}-2 \mathrm{Mn}$ (at.\%) and martensitic morphology was confirmed as shown in Fig. 2(b).

The melting temperature of the composite solder was determined from the heating curve of a DSC profile as 
Table 2. Sample properties for thermal cycling test, chip, substrate and solder.

\begin{tabular}{|c|c|c|c|c|}
\hline (a) Chip & Structure & CTE $\left(10^{-6} /{ }^{\circ} \mathrm{C}\right)$ & \multicolumn{2}{|c|}{ Thickness of interface layer $(\mu \mathrm{m})$} \\
\hline CIC & $\mathrm{Cu} / \mathrm{FeNi} / \mathrm{Cu}$ & 4 & \multicolumn{2}{|c|}{40} \\
\hline IGBT & $\mathrm{Si} / \mathrm{Ni}$ & 4 & \multicolumn{2}{|c|}{0.7} \\
\hline (b) Substrate & Structure & $\operatorname{CTE}\left(10^{-6} /{ }^{\circ} \mathrm{C}\right)$ & \multicolumn{2}{|c|}{ Thickness of interface layer $(\mu \mathrm{m})$} \\
\hline $\mathrm{CIC}$ & $\mathrm{Cu} / \mathrm{FeNi} / \mathrm{Cu}$ & 4 & \multicolumn{2}{|c|}{200} \\
\hline $\mathrm{Ni} / \mathrm{CIC}$ & $\mathrm{Cu} / \mathrm{FeNi} / \mathrm{Cu} / \mathbf{N i}$ & 4 & \multicolumn{2}{|c|}{50} \\
\hline DBA & $\mathrm{Ni} / \mathrm{Al} / \mathrm{AlN} / \mathrm{Al} / \mathrm{Ni}$ & 4 & \multicolumn{2}{|c|}{5} \\
\hline (c) Solder & m.p. $\left({ }^{\circ} \mathrm{C}\right)$ & CTE $\left(10^{-6} /{ }^{\circ} \mathrm{C}\right)$ & Tensile strength (MPa) & Elongation $(\%)$ \\
\hline $\mathrm{Sn}-0.7 \mathrm{Cu}$ & 220 & 22 & 8 & $\sim 20$ \\
\hline $\mathrm{Bi}+\mathrm{CuAlMn}$ & 270 & $10-12$ & 25 & 2 \\
\hline
\end{tabular}

bold: interface layer

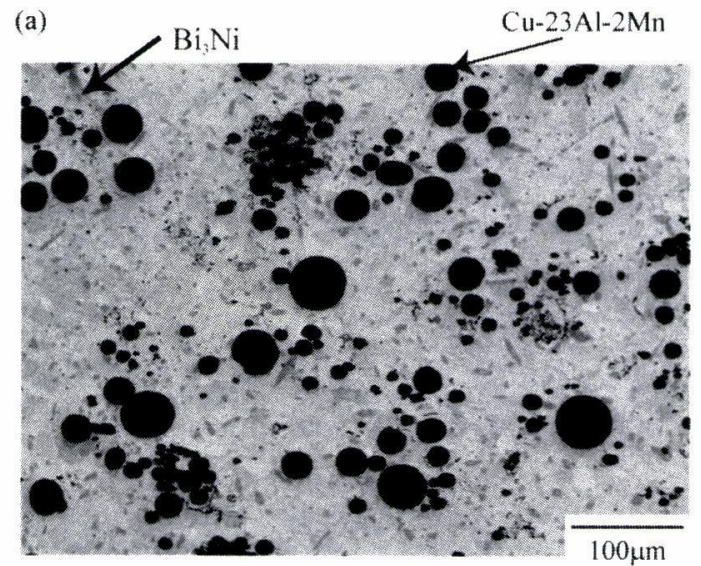

(b) $\mathrm{Cu}-23 \mathrm{Al}-2 \mathrm{Mn}$

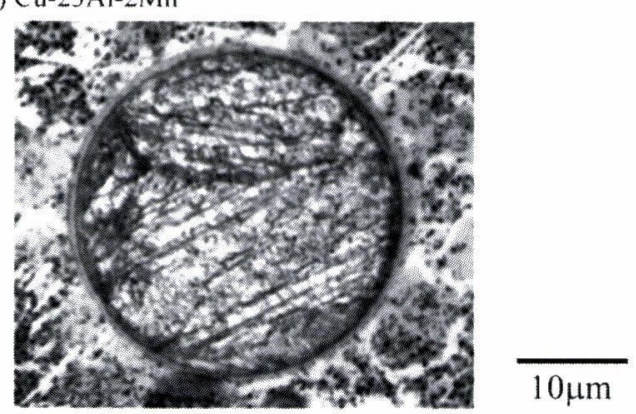

Fig. 2. (a) Cross sectional microstructure of the fabricated $\mathrm{Bi}(60 \%)-\mathrm{Cu}-23 \mathrm{Al}-2 \mathrm{Mn}(30 \%)-\mathrm{Bi}_{3} \mathrm{Ni}(10 \%)$ solder observed by EPMA and (b) martensite state of $\mathrm{Cu}-23 \mathrm{Al}-2 \mathrm{Mn}(\mathrm{at} . \%$ ) particle after the corrosion treatment observed by OM.

shown in Fig. 3. The first sharp peak, which appeared at $270^{\circ} \mathrm{C}$ corresponds to the melting temperature of the $\mathrm{Bi}$ matrix, and the second one represents decomposition of $\mathrm{Bi}_{3} \mathrm{Ni}$ into $\mathrm{BiNi}$ and liquid phases. No peaks caused by martensitic transformation could be detected because the size and volume fraction of $\mathrm{Cu}-\mathrm{Al}-\mathrm{Mn}$ particles is quite small.

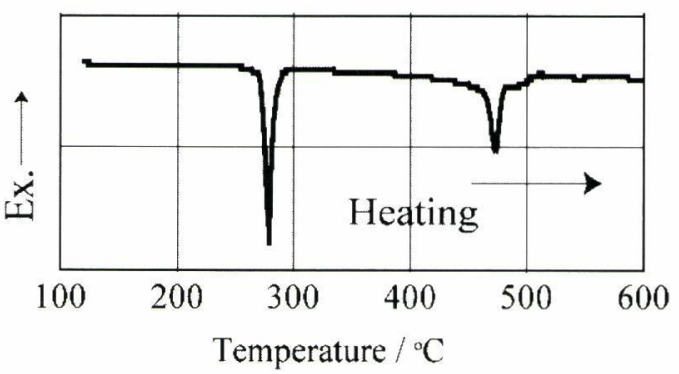

Fig. 3. DSC profile of the fabricated $\mathrm{Bi}(60 \%)-\mathrm{Cu}-23 \mathrm{Al}-$ $2 \mathrm{Mn}(30 \%)-\mathrm{Bi}_{3} \mathrm{Ni}(10 \%)$ solder.

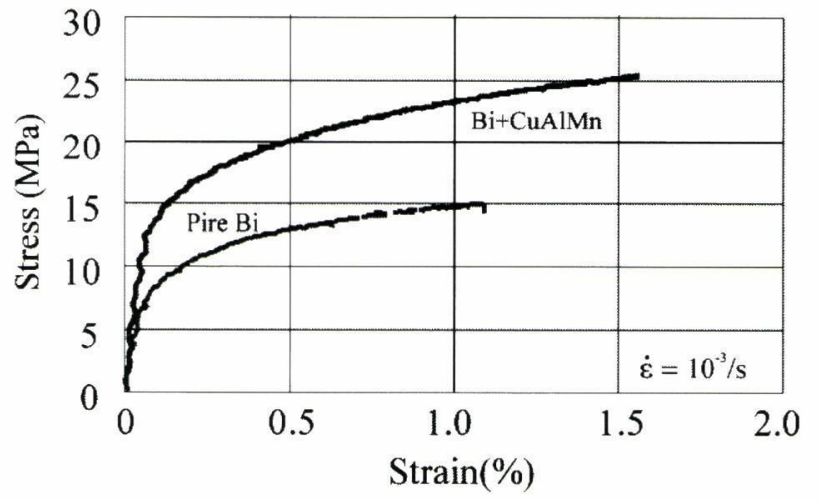

Fig. 4. Stress and strain curve of $\mathrm{Bi}$ and $\mathrm{Bi}+\mathrm{CuAlMn}$ solders at $25^{\circ} \mathrm{C}$.

\subsection{Mechanical properties}

Figure 4 shows stress-strain curves of the composite solder and pure Bi specimens at room temperature. It can be seen that both the tensile strength and the elongation of composite solder are greater than those of pure $\mathrm{Bi}$, which suggests that $\mathrm{Cu}-\mathrm{Al}-\mathrm{Mn}$ particles and $\mathrm{Bi}_{3} \mathrm{Ni}$ precipitates improve the mechanical properties effectively.

The mechanical properties of the composite solder strongly depend on the testing temperature, as shown in 


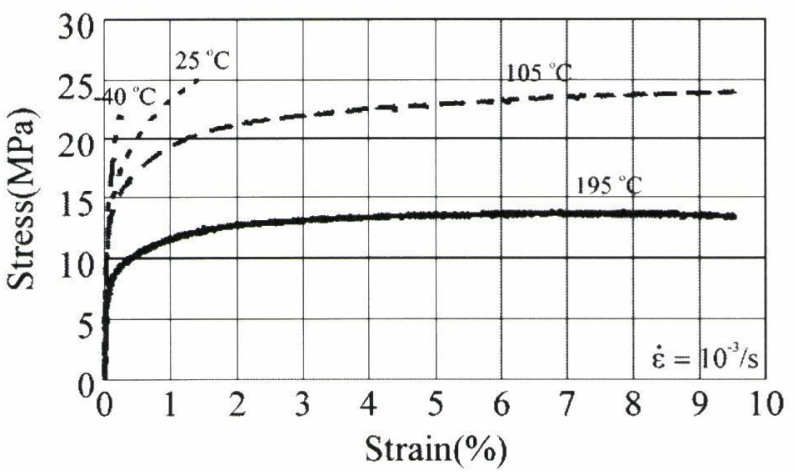

Fig. 5. Stress and strain curve of $\mathrm{Bi}+\mathrm{CuAlMn}$ solders at $-40^{\circ} \mathrm{C}, 25^{\circ} \mathrm{C}, 105^{\circ} \mathrm{C}$ and $195^{\circ} \mathrm{C}$.

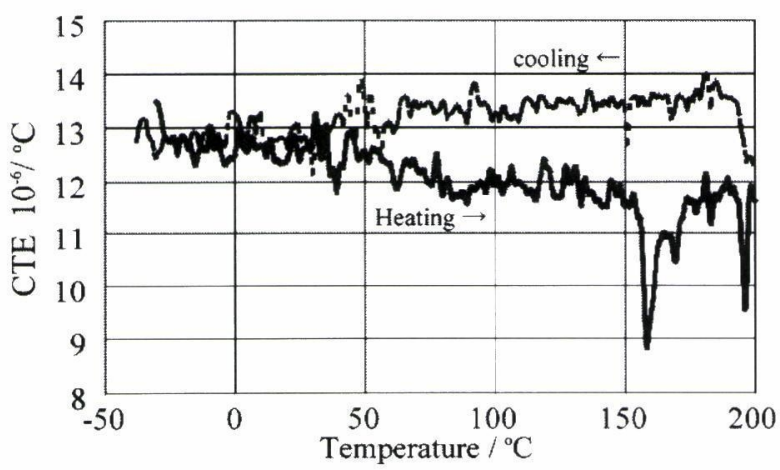

Fig. 6. CTE (coefficient of thermal expansion) curve of the fabricated $\mathrm{Bi}+\mathrm{CuAlMn}$ solder.

Fig. 5. The elongation at $-40^{\circ} \mathrm{C}$ and $25^{\circ} \mathrm{C}$ was only about $0.3 \%$ and $1.5 \%$, respectively. On the contrary, more than $9 \%$ elongation could be obtained at $105^{\circ} \mathrm{C}$ and $195^{\circ} \mathrm{C}$. Tensile strength remained at $13 \mathrm{MPa}$ at $195^{\circ} \mathrm{C}$, which is sufficient strain and strength for high temperature solders.

Figure 6 shows the CTE properties of the composite solder in a wide temperature range between $-40^{\circ} \mathrm{C}$ and $200^{\circ} \mathrm{C}$. At the heating and cooling measurements, the CTE varies from $9 \times 10^{-6} /{ }^{\circ} \mathrm{C}$ to $14 \times 10^{-6} /{ }^{\circ} \mathrm{C}$, which is almost the same CTE value as that of pure $\mathrm{Bi}\left(13.4 \times 10^{-6} /\right.$ $\left.{ }^{\circ} \mathrm{C}\right) .[9]$

The CTE of the Sn base solder and $\mathrm{Pb}$ base high temperature solder exceeds $22 \times 10^{-6} /{ }^{\circ} \mathrm{C}$ and $29 \times 10^{-6} /{ }^{\circ} \mathrm{C}$, respectively, in the same temperature range.[9] On the other hand, the CTE of the semiconductor chip and the substrate for semiconductor devices, is about $4 \times 10^{-6} /{ }^{\circ} \mathrm{C}$, and 4 to $6 \times 10^{-6} /{ }^{\circ} \mathrm{C},[9,10]$ respectively. The thermal stress based on the mismatch of CTE among the chip, solder and substrate certainly causes the formation of cracks, which results in fracture of the assembly, even though $\mathrm{Sn}$ and $\mathrm{Pb}$ exhibit relaxation due to their softness and larger fracture strain. However, the CTE value of the (a)

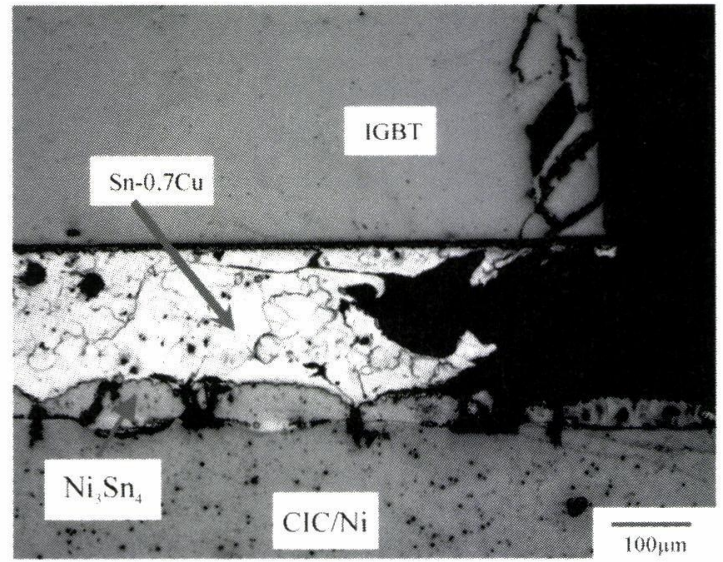

(b)

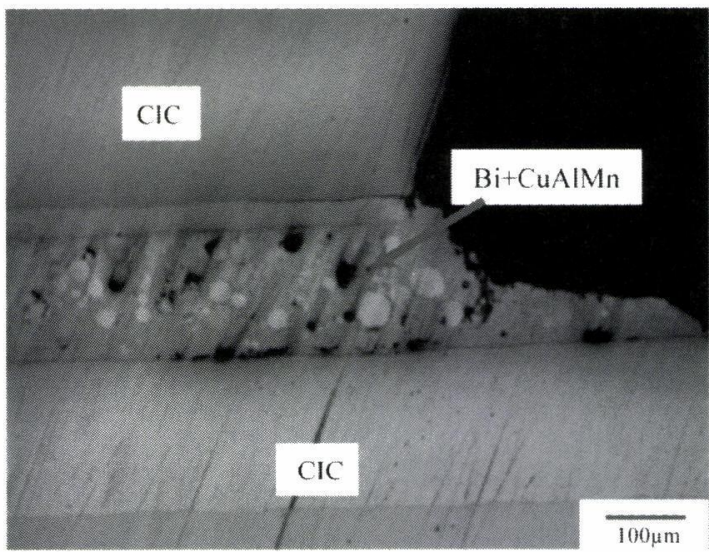

(c)

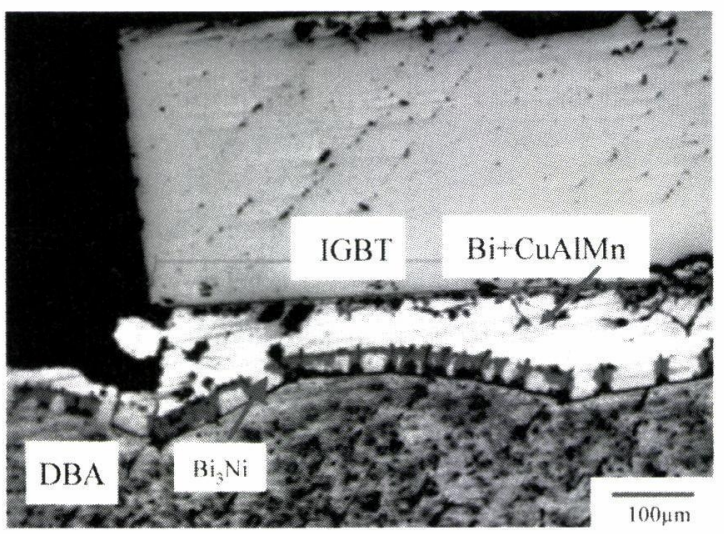

Fig. 7. Cross sectional view of the jointed samples after thermal cycling test of $-40 / 200^{\circ} \mathrm{C}$, (a) IGBT/Sn-0.7Cu/Ni/CIC at 1,513 cycles, (b) CIC/Bi+CuAlMn/CIC at 1,983 cycles, and (c) $\mathrm{IGBT} / \mathrm{Bi}+\mathrm{CuAlMn} / \mathrm{DBA}$ at 1,944 cycles.

Bi base composite solders is smaller than that of conventional $\mathrm{Sn}$ - or $\mathrm{Pb}$-base solders, which is expected to decrease the thermal stress.

\subsection{Thermal cycling test}

Figures 7(a), (b) and (c) show cross-sectional microstructures of IGBT/Sn-0.7Cu/(Ni)CIC, CIC/Bi+CuAlMn/ $\mathrm{CIC}$ and IGBT/Bi+CuAlMn/(Ni)DBA samples after 1,983 
(a)

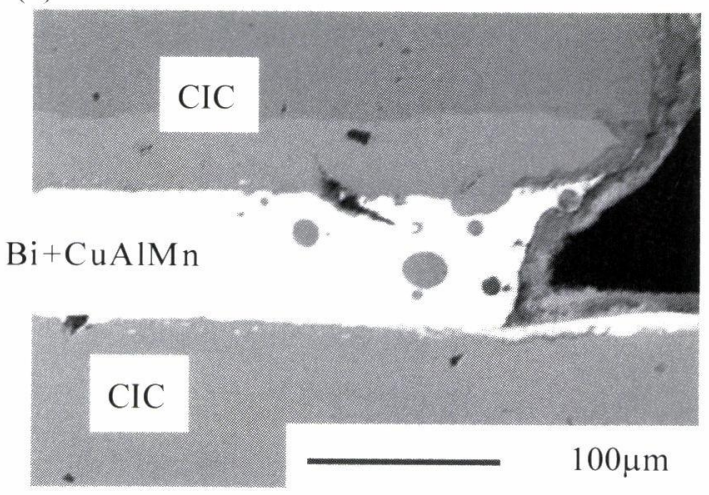

(b)

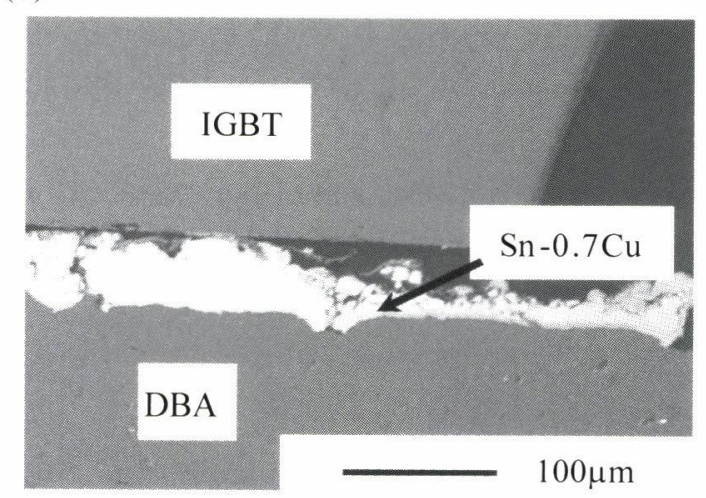

Fig. 8. Cross sectional view of the jointed samples after the thermal cycling test of $-40 / 250^{\circ} \mathrm{C}, 200 \mathrm{cycles}$, (a) $\mathrm{CIC} / \mathrm{Bi}+\mathrm{CuAlMn} / \mathrm{CIC}$ and (b) IGBT/Sn-0.7Cu/DBA.

cycles of the $-40 / 200^{\circ} \mathrm{C}$ thermal cycling test, respectively. It was found that IMC layers of $\mathrm{Ni}_{3} \mathrm{Sn}_{4}$ and $\mathrm{Bi}_{3} \mathrm{Ni}$ formed between the Ni layer and the Sn base and Bi base solders, respectively, whose ductility causes the formation and growth of fatal cracks as shown in Figs. 7(a) and 7 (c). Few cracks and no IMC phase were obtained in the $\mathrm{Bi}+\mathrm{CuAlMn}$ composite solder soldered on $\mathrm{Cu}$ surfaces of the CIC plates as shown in Fig. 7(b). This indicates that (1) no IMC formation warrants the stable soldered interface, and (2) $\mathrm{Cu}-\mathrm{Al}-\mathrm{Mn}$ particles not only have a relaxation effect but also act as a barrier against the growth of cracks. It was also suggested that the CTE values of a chip and a substrate should be matched to avoid fracture due to severe thermal hysteresis. It can be concluded, therefore, that only the interface between the $\mathrm{Cu}$ layer and the $\mathrm{Bi}+\mathrm{CuAlMn}$ composite solder which joined the CTE-matched chip and the substrate exhibited reliable solder joints even after almost 2,000 cycles of the $-40 / 200^{\circ} \mathrm{C}$ thermal cycling test.

Furthermore, no cracks and IMC phases were observed after 200 cycles even at a wider temperature hysteresis between $-40^{\circ} \mathrm{C}$ and $250^{\circ} \mathrm{C}$, as shown in Fig. 8(a). On the other hand, the soldered joint using conventional $\mathrm{Sn}-0.7 \mathrm{Cu}$ solder melted and peeled off during the same test as shown in Fig. 8(b).

\section{Conclusions}

A new type of composite solder which consists of a Bibase matrix and dispersion particles of a $\mathrm{Cu}-\mathrm{Al}-\mathrm{Mn}$ thermoelastic phase alloy was developed. The tensile strength of the developed solder is almost twice as high as pure $\mathrm{Bi}$, while the elongation at elevated temperatures drastically increases up to $9.5 \%$ while retaining its tensile high strength. The dispersion particles with a martensitic structure relax thermal stress due to temperature hysteresis and prevent cracks from extending in the $\mathrm{Bi}$ matrix. A reliable soldered interface which endures severe thermal cycles can be realized when the soldered chip and substrate have a $\mathrm{Cu}$ surface and similar CTE properties, which suggests that the developed composite solder is applicable for temperature hysteresis between $-40^{\circ} \mathrm{C}$ and $200^{\circ} \mathrm{C}$ under appropriate soldering conditions.

\section{Acknowledgement}

The support from CREST-JST and NEDO are acknowledged.

\section{References}

[1] H. Ueda, et al., "High Current Operation of GaN Power HEMTS", Proceed. the 17th Int. Symp. on Power Semicond. Devices \& IC's, IEEE, 311-314 (2005).

[2] K. Asano, et al., "Temperature Dependence of OnState Characteristics, and Switching Characteristics", IEEJ Trans. IA, 125, 147-152 (2005).

[3] Y. Takaku, et al., "Development of Bi-base HighTemperature $\mathrm{Pb}$-Free Solders with Second Phase Dispersion: Thermodynamic Calculation, Microstructure and Interfacial Reaction”, J. Electron. Mater., 35, 1926-1932 (2006).

[4] R. Kainuma, et al., "Thermoelastic Martensite and Shape Memory Effect in Ductile $\mathrm{Cu}-\mathrm{Al}-\mathrm{Mn} \mathrm{Al}-$ loys", Metall. Mater. Trans. A, 27A, 2187-2195 (1996).

[5] R. Kainuma, et al., "Ductile Shape Memory Alloys of the Cu-Al-Mn System", J. de Phys., IV 5, C8 961-966 (1995). 
[6] R. Kainuma, et al., "Phase Equilibria and Heusler Phase Stability in the Cu-Rich Portion of the Cu-Al-Mn System”, J. Alloys Comp., 266, 191-200 (1998).

[7] Y. Sutou, et al., "Enhancement of Superelasticity in $\mathrm{Cu}-\mathrm{Al}-\mathrm{Mn}-\mathrm{Ni}$ Shape-Memory Alloys by Texture Control”, Metall. Mater. Trans. A, 33A, 2817-2824 (2002)
[8] H. Kawakami, et al., "Development of the Electroless Plating Process for the Powder", J. the Surface Finishing Society of Japan, 42, 308-313 (1991).

[9] http://www.boulder.nist.gov/div853/lead \%20free/ solder.html

[10] Y. Yamada, et al., "Pb-Free High Temperature Solders for Power Device Packaging", Microelectronics Reliability, 46, 1932-1937 (2006). 